\title{
極超音速気流中における形状記憶合金製フレームを有する 柔構造体エアロシェルの展開実験*1 \\ Deployment Tests of Membrane Aeroshell with Shape Memory Alloy Frame in a Hypersonic Flow
}

\author{
今 村 宰*2 ·石 田 智 樹*3 - 綿 貫 忠 晴*3 - 鈴木 宏二郎*2 \\ Osamu Imamura, Tomoki Ishida, Tadaharu Watanuki and Kojiro Suzuki
}

Key Words : Membrane Aeroshell, Aerodynamic Heating, Shape-Memory Alloy, Hypersonic, Deployable Structure

\begin{abstract}
For re-entry missions, deployable-flexible aeroshell is expected to have an advantage because it can significantly reduce the aerodynamic heating due to deceleration at relatively high altitudes thanks to its small mass and large area (i.e. low ballistic coefficient), while it can be stowed compactly during the launch phase. In this study, we propose deployable aeroshell supported by the shape memory alloy frame, which can deploy itself automatically by receiving the aerodynamic heating. The present system neither requires additional sensors nor acuators. It seems suitable for small re-entry capsule because of its simple, fault-tolerant and low-cost nature. It is experimentally demonstrated by the wind tunnel tests that a model having a membrane aeroshell with a shape memory alloy frame is smoothly deployed and kept stable in hypersonic flow.
\end{abstract}

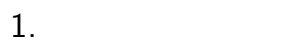

宇宙飛翔体か軌道から再突入する際における技術的な課 題として , 空力加熱が挙げられる . 弚の対策の一つとして 膜面などの柔構造体を利用した低弾道係数の再突入システ ムが提案されている11).機体の面積を大きくすることによっ て弾道係数を小さくすれば, 大気密度の低い高高度から大 きな空気力を受け緩やかに減速することができ，空力加熱 を低減することが可能である.特に膜面などの柔構造体を 用いると，打ち上げ時には折りたたむことによってフェア リング内にコンパクトに収納でき，また再突入時には膜面 を展開し機体面積を増やすことができるため, 空力加熱に 対する対策として有用なシステムであると思われる . 低弾 道係数のメリットは過去にも指摘されているものの, 膜面 を展開・保持する機構を備える必要があり, 弚の信頼性の 確保が困難なため，実現には至っていない，

本報告では，このような低弾道係数を実現する展開可能 な柔構造体として，形状記憶合金を兴のフレームに有する ものを提案する . フレームとして形状記憶合金を用いると， 常温時においては容易に变形が可能でコンパクトに収納で き，一方で再突入時には折りたたまれた形状記憶合金が， 再突入時の空力加熱によって熱せられ，予め記憶された形 状 (ここでは円形状) に変形するため, 形状記憶合金か膜 面の展開機構として作用する . 形状記憶合金は , また温度

\footnotetext{
*1 C) 2007 日本航空宇宙学会

平成 19 年 5 月 18 日原稿受理

*2 東京大学大学院新領域創成科学研究科

*3 東京大学大学院工学系研究科
}

センサーや構造部材の役割も兼ねている .このようなシス テムは, 従来から提案されている展開機構に比べてシステ ムが容易であるため, 耐故障性能, 信頼性に優れ，また小 型軽量化も容易である . しかしながら, 形状記憶合金を膜 面エアロシェルに用いた研究例は報告されていない .

以上のような観点から，形状記憶合金製のフレームを有 する柔構造飛翔体のモデルを作成し，極超音速気流中にお いて同柔構造体の展開実証試験を行った ${ }^{2)}$. 产の実験概要 および結果について以下に示す。

\section{2. 実 験 概 要}

実験は東京大学柏キャンパスの極超音速高エンタルピー 風洞を用いて行われた . 当風洞における設定マッハ数は 7 (圧力比による実測 $6.95 〜 7.10$ ), 本実験におけるよどみ点 圧力 (ノズル上流にて測定, 以下同樣) は $954 \pm 4 \mathrm{kPa}$ で あり，よどみ点温度は 620 ～ $850 \mathrm{~K}$ である . 本風洞ではマッ 八 7 の気流を約 60 秒間持続することが可能である . ノズ ル出口は直径 $200 \mathrm{~mm}$ である .

試作した模型および光の取付け图を第 1 図に示す. 迎角 は 0 度で一定である . 膜面エアロシェルは膜面材の中に形 状記憶合金製の円形状外枠を縫い込むことで作成している． 膜面には強度と難燃性を考慮して ZYLON ${ }^{\circledR}$ (東洋紡) を

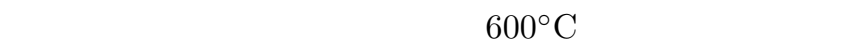
は直径 $1.8 \mathrm{~mm}$ の形状記憶合金をリング状に成型したもの である . 形状記憶合金は Ni-Ti-Cu の合金であり，無応力 状態において $60^{\circ} \mathrm{C}$ 以上で予め記憶された形状に変形する ものを用いた . なお，形状記憶合金のヤング率は実測によ るとジュラルミンと同程度であり ${ }^{2)}$, 展開フレームとして 

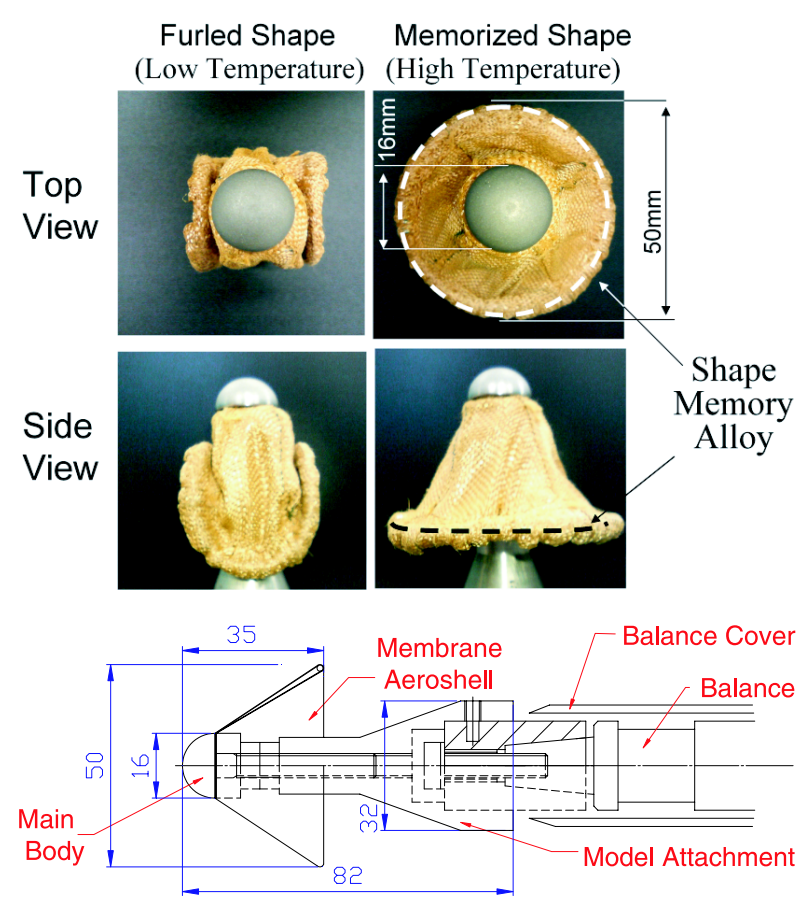

第 1 図 試作した模型と光の取付け図

十分な剛性を有している.第 1 図に示されるように，模型 は展開時に比へてて約半分の大きさに折りたたむことが可能 であった 。

\section{3. 実 験 結 果}

上記の模型を極超音速気流中に投入した際の応答を第 2 図に示す.第 2 図 (b) (c) のシュリーレン写真および直接写 真においては，写真左側が気流上流となっている．模型は 通風を開始してから 20 秒後に気流内に射出投入されてお り，およ光 23.2 秒後に気流中央に到達する (第 2 図の1 1 ) 第 2 図から気流内に投入後, 5 秒程度かけて膜面が展開し ている樣子がわかる . また膜面の展開とともに衝撃波の形 状も変化していることがわかる. 第 2 图 (a)において抵抗 係数 (主流動圧と膜面展開時の前方投影面積で無次元化) は膜面の展開に伴って増加し (2, 3) , 展開後は一定の値 に落ち着く $(3,4,4)$. 本システムにおいては膜面が時間を かけて展開するため，パラシュートなどに見られる開傘衝 撃のような急激な抵抗係数の増加は確認されなかった . こ のように膜面展開時に過度の衝撃が生じないことは, 本シ ステムの利点であると言える．また膜面展開後も風洞が停 止するまで模型形状，抵抗係数ともに安定していた .

第 2 图 (a)には, 膜面を取り除いて行った実験の結果も 合わせて示してある . 抵抗係数の定義は膜面がある場合と 同じである .この図から膜面を含めた飛翔体全体の抵抗は， 膜面がない場合のおよ光 10 倍であり, 再突入時に高高度か ら大きな空気抵抗を受けて減速し, 空力加熱を低減するこ とができると期待される .

このような機体では, 膜面にかかる空気力をフレームの 圧縮力として支えるため, 兴の圧縮力に耐えうるフレーム の断面直径が必要である ${ }^{1)}$. 実機への適応のため機体の大型 (a)
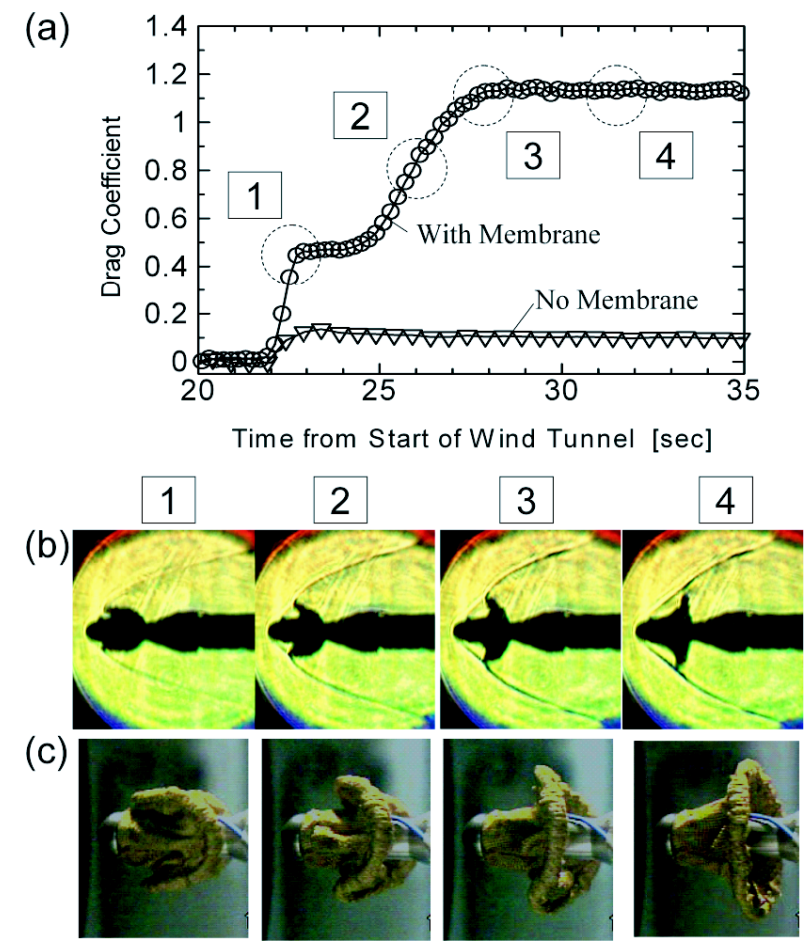

第 2 図 展開の樣子

(a) 抵抗係数, (b) シュリーレン写真, (c) 直接写真

化を考える場合, フレームが構造材として十分な強度を持 つことが必要であるが, 弚れに伴うフレームの重量増加が, 低弾道係数飛行というメリットを損なわないように，十分 な検討をする必要がある。

$$
\text { 4. ま と め }
$$

形状記憶合金製のフレームを有する柔構造飛翔体のモデ ルを作成し，極超音速気流中において同柔構造体の展開実 証試験を行った . 飛翔体のモデルは極超音速気流中に投入後 5 秒程度をかけて展開し, 弚の展開に応じて衝撃波の形状の 変化や抵抗係数の増加か確認された . 本システムはゆっく りと展開するため開傘衝撃を避けることが可能であり，展 開後の形状も安定していた．以上より，形状記憶合金を用 いた柔構造飛翔体は，簡易な構造であるゆえに展開信頼性 の高い機能を有し，かつ相転移温度以下に冷却されるまで 展開状態を保持できるため, 低弾道係数飛行による空力加 熱の低減か期待される.

本研究の一部は日本学術振興会科学研究費補助金基盤研 究 (B) No. 17360408 の支援を受けて行われた . また形状 記憶合金の成型に関し, 東京大学大学院新領域創成科学研 究科の武田 (展) 研究室および同研究室の白石伸夫氏にご 協力いただいた .ここに記して謝意を表する。

$$
\text { 参 考 文 献 }
$$

1) 山田一彦, 鈴木宏二郎 : 柔構造周りの超音速流れと膜面エアロ シェル宇宙輸送機，ながれ，24 (2005), pp. 265-272.

2) 石田智樹: 形状記憶合金製展開フレームを有する柔構造エアロシェ ルの極超音速空力特性に関する研究, 東京大学修士論文, 2006 . 